\title{
Osteopetroses, emphasizing potential approaches to treatment
}



This is the author's manuscript of the article published in final edited form as:

Teti, A., \& Econs, M. J. (2017). Osteopetroses, emphasizing potential approaches to treatment. Bone, 102, 5059. https://doi.org/10.1016/j.bone.2017.02.002 


\begin{abstract}
Osteopetroses are a heterogeneous group of rare genetic bone diseases sharing the common hallmarks of reduced osteoclast activity, increased bone mass and high bone fragility. Osteoclasts are bone resorbing cells that contribute to bone growth and renewal through the erosion of the mineralized matrix. Alongside the bone forming activity by osteoblasts, osteoclasts allow the skeleton to grow harmonically and maintain a healthy balance between bone resorption and formation. Osteoclast impairment in osteopetroses prevents bone renewal and deteriorates bone quality, causing atraumatic fractures. Osteopetroses vary in severity and are caused by mutations in a variety of genes involved in bone resorption or in osteoclastogenesis. Frequent signs and symptoms include osteosclerosis, deformity, dwarfism and narrowing of the bony canals, including the nerve foramina, leading to hematological and neural failures. The disease is autosomal, with only one extremely rare form associated so far to the X-chromosome, and can have either recessive or dominant inheritance. Recessive ostepetroses are generally lethal in infancy or childhood, with a few milder forms clinically denominated intermediate osteopetroses. Dominant osteopetrosis is so far associated only with mutations in the CLCN7 gene and, although described as a benign form, it can be severely debilitating, although not at the same level as recessive forms, and can rarely result in reduced life expectancy. Severe osteopetroses due to osteoclast autonomous defects can be treated by Hematopoietic Stem Cell Transplant (HSCT), but those due to deficiency of the pro-osteoclastogenic cytokine, RANKL, are not suitable for this procedure. Likewise, it is unclear as to whether HSCT, which has high intrinsic risks, results in clinical improvement in autosomal dominant osteopetrosis. Therefore, there is an unmet medical need to identify new therapies and studies are currently in progress to test gene and cell therapies, small interfering RNA approach and novel pharmacologic treatments.
\end{abstract}




\title{
Keywords
}

Osteopetrosis, Osteoclast, Genetics, Therapy

\begin{abstract}
Abbreviations
ADO, Autosomal dominant osteopetroses; ATP6V1B1, V-type proton ATPase subunit B, kidney isoform; CAll, carbonic anhydrase type II; Cas9, CRISPR associated protein 9; CLCN7, Chloride channel 7; CRISPR, clustered regularly interspaced short palindromic repeats; CTX, Carboxyterminal collagen crosslinks; HEK293, Human embryonic kidney cells 293; HLA, Human leukocyte antigen; HSCT, Hematopoietic stem cell transplantation; IFN- - , Interferon- - ; IKBKG, inhibitor of nuclear factor kappa-B kinase subunit gamma; IKK, IKB kinase; iPSCs, Induced pluripotent stem cells; LRP5, Low-density lipoprotein receptor-related protein 5; NEMO, NF-kappa-B essential modulator; OSTM1, Osteopetrosis-associated transmembrane protein 1; PLEKHM1, Pleckstrin homology domain-containing family $\mathrm{M}$ member 1 ; PTH, parathyroid hormone; RANK, Receptor Activator of NF-KB transcription factor; RANKL, Receptor Activator of NF-KB transcription factor Ligand; siRNA, small interfering RNA; SNX10, sorting nexin family; TCIRG1, V-type proton ATPase 116 kDa subunit a isoform 3; TNFRSF11A, Tumor Necrosis Factor Receptor Superfamily, Member 11a, NFKB Activator; TNFSF11, Tumor Necrosis Factor Superfamily Member 11; TRAcP, tartrateresistant acid phosphatase.
\end{abstract}




\section{Introduction}

Osteoclasts are the bone resorbing cells that, with their mineralized matrix erosion activity, contribute to the harmonic skeletal growth and continuous renewal of the tissue (1). The result of this intense activity is a balanced bone modeling and remodeling keeping bone healthy and mechanically competent (2).

The hallmark of all osteopetroses is reduced osteoclast activity $(3,4)$. This impairment results in excessive bone mass, with a paradoxical decrease in bone strength. Osteopetroses are best classified based on their inheritance pattern. Recessive disease, which can be due to biallelic mutations in several genes, is generally very severe (5). Mutations in the gene coding for carbonic anhydrase tend instead to result in a more moderate phenotype, but with cognitive disabilities, as well as other morbidities (6). The dominant form of osteopetrosis, due to dominant negative mutations in the CLCN7 gene, can result in mild, moderate, but also severe disease, although with less infirmities than autosomal recessive forms (7-12).

In this article, we describe the various forms of osteopetrosis and emphasize current and future approaches to therapy.

\section{Classification and clinical findings}

\subsection{Recessive osteopetroses}

The recessive forms of osteopetrosis have a combined prevalence of 1:250,000 live births and are due to mutations in several genes and a molecular diagnosis is obtainable for most patients (3-5). They are generally lethal within the first few years of life, with some survivors who may achieve childhood or early adolescence (3-5). These forms are characterized by brittle bones, which 
radiologically appear diffusely dense, with long bone funnel-like extremities and alternating radiolucent lines, and extremely narrowed medullary cavities with bone-in-bone appearance (3-5) typical of growth arrest, consisting in denser marginal areas of mineralization, intermediate less dense areas and innermost denser areas (13). These features are pathognomonic and allow an accurate radiological diagnosis compared to other high bone mass conditions (14).

The reduced size of the medullary cavities constrains the bone marrow leading to hematological failure (3-5). In fact, the early signs of recessive osteopetroses are anemia, leucopenia and susceptibility to infections (3-5). Infants also suffer from dwarfism, frontal bossing, deformities, osteomyelitis, hydrocephalous, and neurological symptoms $(3-5,15)$. Blindness/visual loss is frequently present at diagnosis and, in the majority of patients, they are due to nerve compression caused by the narrowing of the poorly resorbed nerve foramina (3-5). Cognitive function is frequently normal except in recessive syndromes due to OSTM1 and, less frequently, to CLCN7 gene mutations which cause primary neurodegeneration due to lysosomal storage disease affecting various areas of the brain, including cerebral and cerebellar cortices, hippocampus and retina $(16,17)$. Furthermore, in other forms (gene implicated TCIRG1), patients also display increase of gastric $\mathrm{pH}$, which may limit calcium absorption and contribute to hypocalcemia (1920). Based on data in mice (21), a similar increase of gastric $\mathrm{pH}$ could be hypothesized in patients harboring $S N X 10$ mutations.

There is a very high fracture rate in recessive patients due to poor quality of the non-remodeled bone $(3-5,7)$. Moreover, these fractures show defective healing. Additionally, there is a high incidence of osteomyelitis most likely due to a combination of increased susceptibility to infections and poor blood flow to bone. In some patients (genes implicated TNFRSF11A), the poor 
response to infections could be aggravated by a partial defect in the B-cell compartment (22), with a severity that increases with age and the progression of the disease. The TNFRSF11A and TNFSF11 forms are also characterized by the inability to generate osteoclasts $(22,23)$ and are classified as osteoclast-poor osteopetroses, as opposed to the other forms in which the numbers of nonfunctional osteoclasts are normal or even higher than normal, and are classified as osteoclastrich osteopetroses (24).

The analysis of serum biomarkers of bone turnover has revealed that recessive patients are hypocalcemic, present with elevated alkaline phosphatase (osteoblast biomarker), reduced bone resorption biomarkers and increased brain creatin-kinase, a biomarker of uncertain meaning but rather consistently deregulated in osteopetroses $(25,26)$. Since most forms of osteopetrosis are osteoclast-rich, tartrate-resistant acid phosphatase (TRACP), an osteoclast biomarker, is increased, in line with the increased numbers of osteoclasts. In contrast, in osteoclast-poor osteopetrosis the serum level of TRACP is significantly lower than the normal values (25). Bone marrow aspirates in all forms of recessive osteopetrosis reveal severely reduced cellularity, while bone biopsies show persistence of primary trabeculae characterized by a core of calcified cartilage, typical of nonremodeled bone (3-5).

Mutations in the gene coding for carbonic anhydrase type II (CAII) cause an autosomal recessive osteopetrosis with variable severity (6). It is sometimes referred to as "intermediate osteopetrosis". The exact prevalence is unknown, but it is rare. It presents not only with osteopetrosis, but also with renal tubular acidosis, cognitive impairment and cerebral calcifications (27). Paradoxically, in some subjects skeletal symptoms improve with age, although short stature, deformities, cognitive impairment and visual and hearing impairment persist. This might occur 
because low $\mathrm{pH}$ stimulates osteoclast activity, therefore, acidosis could mitigate their impairment (28).

\subsection{Dominant osteopetroses}

Autosomal dominant osteopetroses (ADO) are still referred to as type 1 and type 2 . Type 1 is typically very mild but it appears now to be misclassified, being due to mutations of the LRP5 gene, which affect osteoblasts $(29,30)$. Therefore, it should be considered a "high bone mass" syndrome rather than an osteopetrosis. ADO2 (also known as "Albers-Schönberg disease" and "marble bone disease") has a prevalence of approximately 1:20,000 live births (7) and a penetrance of approximately $66 \%$ (31). Because of the incomplete penetrance and a mild or asymptomatic phenotype in some individuals with CLCN7 gene mutations, ADO2 is sometimes referred to as the "benign" form of the disease to distinguish it from the "malignant" recessive form, which is generally lethal in infancy $(3-5,7)$. However, this "benign" designation is a misnomer and most ADO2 patients suffer complications from their disease. In our previous study, hip or femur fractures occurred in $16 \%$ of $A D O 2$ children and $49 \%$ of $A D O 2$ adults and our 4 most severely affected patients have died (25,31, Econs, unpublished observations). In our population, there was a high rate of severe visual loss due to lack of bone resorption to widen the optic canal during growth, with an overall prevalence of $19 \%$. Additionally, $16 \%$ of our patients had osteonecrosis or osteomyelitis and bone marrow failure occurred in $3 \%$ of patients (31). Similar to our study, Benichou et al (32) studied 42 ADO2 patients and found that $78 \%$ of them had fractures and over half had orthopedic procedures with half of those having at least 3 procedures. They also had a high rate of mandibular osteomyelitis (12.9\%). In contrast to our study (31), only $5 \%$ of patients had visual loss due to optic nerve compression (32). Thus, despite the high variability in the phenotype, ADO2 patients manifest significant, and in some cases, severe disease. 
Radiologically, patients frequently show osteosclerosis of the skull base, pelvis and vertebras $(3,7,31,32)$. These latter give rise to the so-called rugger-jersey spine because of the prominent multiple contiguous subendplate densities (sandwich vertebras), radiologically causing an alternating dense-lucent-dense appearance $(3,7,31,32)$. Blood levels of TRACP and the brain isoform of creatin-kinase are elevated $(25,33,34)$. Low red cell and white cell counts occur in the most severely affected patients due to bone marrow failure $(25,31,32)$. Thus, ADO2 displays incomplete penetrance and variable expressivity with some patients being quite severely affected.

\section{Cellular overview}

Osteopetroses are osteoclast diseases, and they have been extremely important to understand various aspects of osteoclast biology, including the hematological and circulating origin of their precursors $(35,36)$ as well as the molecular mechanisms of bone resorption (37). The understanding of these cellular features has been greatly facilitated by the availability of rodent models of osteopetroses, spontaneously occurring in mice and rats (37-39), and more recently obtained in mice by genetic manipulations $(40,41)$. As stated above, based on the abundance of osteoclasts, osteopetroses are classified in two groups: osteoclast-rich, in which osteoclast numbers are normal or, more often, high, and osteoclast-poor, showing no osteoclasts (24). This classification highlights the ability of the individuals affected by the former to generate osteoclasts through the canonical osteoclastogenic pathways, and the inability of do so of those affected by the latter (24).

\subsection{Osteoclast-rich osteopetroses}

Osteoclast-rich osteopetroses represent the most frequent conditions, both in rodents and humans (24). They are seen in patients affected by recessive and dominant osteopetroses and, as 
already stated, are characterized by normal or high serum levels of TRAcP, despite reduced biomarkers of bone resorption. Bone biopsies show normal or, most frequently, high number and surface of osteoclasts/bone surface, with low erosion surface/bone perimeter (25). Osteoclasts are easily recognized in bone biopsies through the histochemical detection of TRAcP (42). They line the bone surface but do not excavate Howship lacunas, a clear sign of impaired bone resorption. In several cases, the number of nuclei/osteoclast is high, suggesting that there is no impairment of fusions of precursors. At the transmission electron microscope, these osteoclasts may present imperfect polarization and lack of the ruffled border (43).

In early studies, the high osteoclast number was thought to be an intrinsic feature of the disease. Later, the role of parathyroid hormone (PTH) in osteoclastogenesis was discovered (44) and clarified the origin of this cellular feature. PTH release is stimulated by low serum calcium concentration (45). Along with an intense osteoblast anabolic role (46), this hormone shows the peculiar ability to induce the production by osteoblasts of the most potent osteoclastogenic cytokine, Receptor Activator of NF-KB transcription factor Ligand (RANKL

RANKL) (47). Favored by a concomitant reduction of the RANKL decoy receptor, osteoprotegerin (47), the excess of free RANKL stimulates osteoclast formation, with the unmet aim in osteopetrotic patients to return the calcemia to normal level. It is clear though that the osteoclastogenic process in osteoclast-rich osteopetroses is not disturbed, and that the molecular failure is within the mechanism of bone resorption (24). However, in ADO2 osteoclast number is high despite normal PTH concentrations, and in these patients it has been suggested that osteoclasts exhibit a prolonged lifespan caused by a yet to be determined pathway stimulating survival $(48,49)$. 
Of note, in bone biopsies of patients with osteoclast-rich autosomal recessive osteopetroses the small bone marrow still present in the narrow medullary cavities is strongly fibrotic with scant hematopoietic tissue left $(25,42,50)$.

\subsection{Osteoclast-poor osteopetroses}

Much rarer in humans are the cases of osteoclast-poor osteopetroses. They represent a small percentage of the totality of cases of autosomal recessive osteopetroses and are characterized by low serum levels of TRACP and no TRAcP-positive osteoclasts in bone biopsies (25). In these patients, the process of osteoclastogenesis is impeded by the lack of the osteoclastogenic cytokine RANKL (22), or of its receptor RANK (23). The former is a defect of the osteoblasts and other RANKL producing cells, including osteocytes and lymphocytes. The latter is an osteoclastautonomous defect due to lack of response to RANKL by the osteoclast precursors. Interestingly, at variance with the osteoclast-rich forms, in osteoclast-poor osteopetroses the small bone marrow tissue still present in the bone is not fibrotic, with some hematopoiesis still active (50), which could explain why patients survive longer.

\section{Genotype-phenotype correlation}

The various clinical forms of osteopetrosis have recognized genetic traits (Table 1), with only less than $25 \%$ of patients harboring yet to be discovered gene mutations (5).

\subsection{Recessive osteopetroses}

About $50 \%$ of patients with autosomal recessive osteopetroses harbor mutations of the TCIRG1 gene, which codes for the a3 subunit of the $\mathrm{V}-\mathrm{H}^{+} \mathrm{ATPase}$ localized in the osteoclast ruffled border and in the gastric gland parietal cell apical membrane, where it releases protons to acidify the 
extracellular environment $(19,51)$. In osteoclasts, this environment, called Howship or resorption lacuna, is localized underneath the cell, between the ruffled border and the bone matrix, sealed at the periphery by the sealing membrane through its podosomal actin ring (1). Since the hydroxyapatite is strongly soluble in an acidic environment, this low $\mathrm{pH}$ demineralizes the bone, exposing the organic matrix to the lysosomal enzymes therein released, especially cathepsin $\mathrm{K}$, which cleaves type I collagen in small fragments (52). In the gastric gland parietal cells, protons are released into the lumen where the gastric juice denatures and digests the protein content of the food. Gastric acidification is also essential for calcium uptake through the gastro-intestinal tract, the consequence of which in this form of the disease is, as already stated, a rickets- or osteomalacia-like phenotype that adds to the osteopetrotic phenotype $(19,20)$.

Osteopetrotickets or osteopetromalacia are not observed in bone biopsies of forms of autosomal recessive osteopetroses due to loss-of-function mutations of the CLCN7 and the OSTM1 genes. Patients harboring CLCN7 or OSTM1 gene mutations display an overlapping phenotype $(16,17)$, with some differences compared to those affected by TCIRG1 or SNX10 gene mutations. This observation suggests that the two proteins are implicated in the same molecular cascade (53). In fact, the CLCN7 gene codes for the CIC-7 protein, which is a 2-chloride/1-proton antiporter localized in the acidic vesicle and ruffled border membranes. CIC-7 charge balances the positive protons that are discharged by the $\mathrm{V}-\mathrm{H}^{+} \mathrm{ATPase}$ and releases chloride ions essential for acidifying the osteoclast lacunae space (16). OSTM1 encodes for the Ostm1 protein, which is classified as the CIC-7 $\beta$-subunit, essential for the correct trafficking and subcellular localization of the CIC-7 (53).

As mentioned above, the peculiar phenotype of these forms of osteopetrosis is a severe primary neurodegeneration observed in brain and retina $(16,17)$. This phenotype is due to a lysosomal 
storage disease and is most reproducible in OSTM1-patients, while the situation is more heterogeneous in CLCN7-patients (18).

The $\operatorname{SNX10}$ gene mutations affect about $4 \%$ of patients with recessive osteopetroses $(5,54)$ and is characterized by few and small osteoclasts (54). The protein coded by this gene interacts with the $\mathrm{V}-\mathrm{H}^{+}$ATPase and is probably involved in the sorting of this complex to the ruffled border (54). Osteoclasts from mouse models of SNX10 deficiency show defective endocytosis, extracellular acidification and ruffled border formation, which leads to impaired bone resorption (54). The protein is also expressed in the stomach, where high $\mathrm{pH}$ and low calcium solubilization are observed (22). Consequently, the $S N X 10$ global knock-out mouse bone phenotype is consistent with osteopetrorickets, as opposed to the osteoclast-specific knock-out mice that show ostepetrosis but not rickets (21).

Two genes whose mutations are known to cause severe osteopetroses code for the osteoclastogenic cytokine RANKL (TNFSF11) expressed by the osteoblasts, and its receptor RANK (TNFRSF11A) expressed by the osteoclast precursors, accounting for $5 \%$ of patients each (55). The RANKL/RANK pathway is implicated in the process of osteoclast formation, therefore these forms of osteopetrosis are osteoclast-poor (24), and in bone biopsies the TRAcP histochemical staining detects no positive cells (25). Paradoxically, these patients survive a bit more than those affected by the other forms described above, although they are severely compromised and some of those affected by TNFRSF11A mutations suffer also from hypogammaglobilinemia (22).

The only X-chromosome-linked osteopetrosis occurs in the so-called OL-EDA-ID syndrome characterized by lymphedema, anhidrotic ectodermal dysplasia and immunodeficiency. Patients 
show a moderate osteopetrosis with no neurosensory impairments (56). The gene implicated is called IKBKG and codes for NEMO, the regulatory subunit of the IKK complex, essential to activate the NF-KB transcription factor and induce osteoclastogenesis. OL-EDA-ID is lethal in early infancy and there are no studies on its prevalence in the osteopetrotic population. However, according to the paucity of data in literature, it is likely to be a very rare disease in which osteopetrosis is not the most severe condition. Since NEMO belongs to the osteoclastogenic signaling cascade (57), it is thought that OL-EDA-ID displays an osteoclast-poor osteopetrosis. However, no data are available in literature therefore the cellular alterations occurring in the bones of these patients remain to be elucidated. Furthermore, this form is currently untreatable due to the severity of manifestations besides osteopetrosis.

An autosomal recessive loss-of-function mutation of the PLEKHM1 gene has been found to induce a moderately severe form of osteopetrosis (39). Plekhm1 is a protein involved in vesicular trafficking, the mutation of which prevents the formation of the osteoclast ruffled border and impairs the resorption of bone (39). Plekhm1 is associated with small GTPases, and is co-localized with Rab7 in late endosomes and lysosomes, which are major contributors of membrane transport to the ruffled border $(39,58)$.

Autosomal recessive loss-of-function mutations of the CAll gene, coding for carbonic anhydrase type 2, are responsible for what was sometimes referred to as "intermediate osteopetrosis" (6). This cytosolic enzyme catalyzes the hydration of $\mathrm{CO}_{2}$ into $\mathrm{H}_{2} \mathrm{CO}_{3}$, supplying the $\mathrm{V}-\mathrm{H}^{+} \mathrm{ATPase}$ with protons derived by the $\mathrm{H}_{2} \mathrm{CO}_{3}$ dissociation (40). The resulting $\mathrm{HCO}_{3}^{-}$is exchanged with chloride by an anion exchanger located in the osteoclast basolateral membrane $(59,60)$, which in turn fuels the ruffled border CIC-7 antiporter. The CAll gene is highly expressed also in the kidney tubular 
cells (61), therefore these patients present with renal tubular acidosis, which is a specific hallmark of this form of osteopetrosis (40). The reason why this form has a milder course than other forms of recessive osteopetroses is believed to depend on a low rate of spontaneous $\mathrm{CO}_{2}$ hydration occurring into the cells, therefore, even in the absence of a functional carbonic anhydrase, the acidification of the lacuna is not totally prevented. Furthermore, an improvement of the bone phenotype may be seen with time, probably due to the beneficial effect of acidosis on osteoclast function (28). In contrast, patients suffer from cerebral calcifications of unknown origin, which challenge the neural function inducing cognitive impairment (40).

Finally, a peculiar and very rare form of severe osteopetrosis can be confused with CAll deficiency. Borthwick et al. (62) identified in a patient penetrant mutations in two different genes. One mutation was a homozygous deletion in the TCIRG1 gene, which was associated with a homozygous mutation in the ATP6V1B1 gene coding for the $\mathrm{B} 1$ subunit of the $\mathrm{V}-\mathrm{H}^{+}$ATPase specifically expressed in the kidney. The result of this complex genetic trait was a severe osteopetrosis, with renal tubular acidosis that phenocopied the CAll deficiency.

\subsection{Autosomal Dominant Osteopetroses}

The only gene implicated so far in dominant forms of osteopetrosis is the CLCN7, in which various types of mutations cause ADO2 by a dominant negative mechanism (8-12, 63-68). As noted above, ADO1, which is caused by mutations in the LRP5 gene, should be reclassified as affected by high bone mass syndrome (29).

The CLCN7 gene codes for the CIC-7 subunit of the $2 \mathrm{Cl}^{-} / 1 \mathrm{H}^{+}$antiporter localized in the acidic vesicles and ruffled border compartment of the osteoclast (53). This subunit dimerizes and 
associates with the Ostm1 protein, which is essential for its correct localization (53). Through its stoichiometry of 2 chlorides against 1 proton, the antiporter releases negative charges into the acidic vesicles and the Howship lacuna, which balance the transport of positive charges by the V$H^{*}$ ATPase (1). Since the CLCN7 gene is haplosufficient, its biallelic loss-of-function mutations can only cause the autosomal recessive osteopetrosis described above as a severe form of the diseases, while heterozygous subjects are healthy carriers (16). In contrast, in ADO2, the gene harbors mostly missense mutations with dominant negative feature, in which the mutant subunits can still dimerize although they have impaired function (53). Consequently, an assortment of normal homodimers and mutated homo- and heterodimers are believed to be expressed by patients.

Interestingly, the mutant CLCN7 gene has an incomplete penetrance, accounting for about $66 \%$ of patients presenting with symptoms (31). The remaining patients are healthy, can be considered normal carriers and are generally recognized through the genetic screening of the affected families (31). Many families have both non-penetrant carriers and severely affected individuals. The molecular mechanisms of the incomplete penetrance remain to be elucidated. The gene is made up by 25 exons and is highly polymorphic (69), but it is unclear whether specific polymorphisms could be associated with its incomplete penetrance (69-71). Environmental modifiers, genetic modifiers as well as epigenetic regulation could represent other mechanisms favoring the incomplete penetrance, but further work is necessary to discover those specifically modulating the expression of the dominant negative CLCN7 gene mutants. Understanding these features could help identify new and specific molecular targets for therapy. 
The affected patients display a wide variety of symptoms, ranging from solely radiographic features to repeated atraumatic fractures, as well as compromised vision and hearing and occasional bone marrow failure $(31,32)$. Furthermore, since the CLCN7 gene is widely expressed in the body, it is unlikely that the bone is the only affected tissue. Since the loss-of-function mutations of the CLCN7 gene in the autosomal recessive osteopetrosis may also induce neurodegeneration, attention should be paid to central neural disorders. Generally, they are not reported in patients with ADO2, although rare cases of cognitive failure are known (25). However, a recent mouse model carrying the $\mathrm{ClC}-7^{\mathrm{G213R}}$ mutant in heterozygous status shows increased anxiety and depression correlated with accumulation of $\beta$-amyloid bodies in neurons (72). Whether anxiety and depression is a primary consequence of the genetic defect in humans as well or if these conditions result from being chronically ill is unknown. Furthermore, the CLCN7 gene exhibits significant expression in various organs and in our ADO2 mouse model we observed a mild multiorgan perivascular fibrosis that is several-fold aggravated in the homozygous status (Teti, unpublished information), which could contribute to the early death of the mice within the first month of life (73). Further studies should be performed in patients to determine if they also display a phenotype in other organs.

\section{Therapy of osteopetroses}

\subsection{Current therapies}

As noted, mouse models of osteopetroses have been instrumental to identify the hematologic and circulating origin of the osteoclast precursors $(35,36)$. These observations indicated that HSCT would be a useful therapy for many forms of autosomal recessive osteopetroses (74). Although there have been many improvements in HSCT over the years, it remains a dangerous procedure with many toxicities (18). Therefore, it is reserved for patients with severe disease. 
These patients typically have recessive disease and there is no data to determine whether HSCT works in severe cases of $A D O 2$, although the bone disease in these patients can also be very debilitating.


non-autonomous form due to mutation of RANKL, and of the OSTM1 and, less frequently, the CLCN7 genes mutations.

In RANKL deficiency, the hematopoietic stem cells cannot replace the stromal/osteoblast cells that produce the mutant RANKL $(23,75)$. These cells belong to the skeletal stem cell lineage and support skeletal regeneration, hematopoiesis and osteoclastogenesis (76). Their transplant could in theory supply the healthy cytokine, but their use in medicine is still limited (77), although progress is being made for instance for the treatment of pediatric diseases, including the osteogenesis imperfecta (78-80). Furthermore, the engraftment of mesenchymal stem cells has been met with unexpected difficulties, which again limit their current use for therapies in humans $(76,77)$. However, intense investigation is being performed, especially showing mesenchymal stem cell homing to sites of inflammation or tissue damage, where they seem to adsorb immunosuppressive drugs enhancing their immunomodulator properties (81) as well as their potential for the treatment of graft versus host disease (82).

Osteopetroses due to biallelic mutations in the OSTM1 and the CLCN7 genes in theory can be treated with HSCT. However, the serious neurodegeneration observed in brain and retina, especially in OSTM1 deficient patients, cannot be cured by this procedure, therefore cognitive function and vision remain severely compromised (18). However, while the OSTM1 form 
constantly presents with severe neuropathy, patients with CLCN7 gene mutations may be free of neurodegeneration (18). Therefore, it is current practice to carefully evaluate CLCN7 patients neurologically and consider HSCT if there are no or limited signs of neurological impairment (18).

\begin{abstract}
Although HSCT is a risky procedure, in recent years many outstanding centers made significant improvements, saving lives of an increasing number of patients (83). However, HSCT still presents some pitfalls. Engraftment problems may consist in delay of hematological recovery, active rejection especially in patients transplanted with HLA-haploidentical stem cells above 10 months of age, stable mixed chimerism and extinction of donor cells, which may require a second transplant (18). Further complications may be represented by graft versus host disease, liver or pulmonary veno-occlusive disease, respiratory problems with upper airway obstruction, secondary ventilation problems due to fluid overload, infections and primary pulmonary hypertension (18). Hypercalcemia is also observed, especially after HLA-identical transplant, which can require treatment with anti-resorptive drugs, including bisphosphonates or denosumab (18).
\end{abstract}

Although the treatment regimen with HSCT is effective in restoring normal bone resorption and hematopoiesis, there are still some drawbacks that affect the children. In a systematic retrospective study performed between 1980 and 2001, it appeared clear that the 5 years disease free survival was dramatically affected by the HLA genotype of the donors. While HLA-identical recipients had a chance of survival greater than $70 \%$, this chance dropped to about $40 \%$ for recipients of HLA-mismatch transplant from a related donor or matched unrelated donor, down to 24\% for children receiving a graft from a HLA-haplotype-mismatch related donor (15). However, improvement is constantly observed in more recent years for all transplant groups, especially in the case of HLA-haploidentical transplant, whose rate of success has been assessed around $60 \%$ 
from 1993 to 2007 (18). Death after transplant is most frequently due to graft failure and earlytransplant complications, which makes this treatment regimen unfeasible for intermediate and milder forms of osteopetroses.

\begin{abstract}
Death is not the only severe post-transplant negative outcome. Visual impairment is often not cured because of optical nerve atrophy that cannot be restored (15). However, it has been observed that visual preservation or improvement is more frequent in children transplanted below 3 months of age (15), highlighting the importance of rapid diagnosis and therapy. Likewise, dwarfism, cognitive impairment (if present), and primary neuropathy in OSTM1 and in CLCN7 (if present) loss-of-function gene mutations, are not cured by HSCT. Nevertheless, when successful, HSCT can lead to a relatively good quality of life (18).
\end{abstract}

When HSCT is not possible, alternative therapies are employed. However, they cannot replace HSCT as they are not curative interventions. Interferon- $\gamma$ (IFN- - ) is approved for use in severe recessive osteopetroses, but currently it is not included in the common clinical practice. In fact, it is only used as a bridge therapy to allow patients to survive until an acceptable donor for HSCT is found and, to the best of our knowledge, there are no recent reports updating on the clinical outcome. In a study published in 1995, Key et al. (84) treated 14 patients with recessive osteopetroses with IFN- $p$. After 6 months of therapy, all patients demonstrated decreases in trabecular bone area and increases in marrow space. Mean hemoglobin concentration increased (from $7.5 \pm 2.9 \mathrm{~g} / \mathrm{dL}$ to $10.5 \pm 0.3 \mathrm{~g} / \mathrm{dL}$ ), demonstrating improvement in bone marrow function. Superoxide generation increased and there was a marked reduction in infections. Improvements were sustained in the 11 patients who were treated for 18 months. Thus, IFN- $\gamma$ is a useful therapy while waiting for a suitable donor for HSCT. 
Currently, there are no accepted therapies for dominant osteopetrosis and, unfortunately, for many patients with either recessive or dominant osteopetroses the major thrust of therapy is supportive. This includes blood transfusions for bone marrow failure and frequent orthopedic procedures to attempt to stabilize fractures. Of note, orthopedic procedures are frequently difficult and the risk of infection is high (85). Additional supportive therapies include analgesics to reduce pain and antibiotics to treat osteomyelitis. Previous therapies with PTH, vitamin D3 and calcium supplementation (86-89) have resoundingly failed. Furthermore, patients affected by RANKL deficiency cannot benefit from HSCT therefore this form of severe osteopetrosis is currently incurable. Thus, there is a critical need to better understand the pathogenesis of these disorders to find new and effective interventions.

\subsection{Future therapies}

As noted above, it is clear that scientists must continue to investigate the natural history of the disease to find alternative strategies. Fortunately, a number of studies are already in progress and could lead in reasonable time to therapeutic innovations.

Being a hematologic disease, future approaches could be based on gene therapy, at least for the severe forms. This approach could liberate patients from the need to search HLA-matched donors, as it would allow the correction of the genetic disease in autologous hematopoietic stem cells (90). Recent success of classical gene therapy by lentivirus transduction used to cure congenital immunodeficiencies (90) is very promising. Equally promising are the new approaches of genome editing, especially through the CRISPR/Cas9 technology (91). Likewise, recent studies have emphasized the theoretical possibility to use corrected autologous induced pluripotent stem cells 
(iPSCs) (92). iPSCs injected in immunodeficient mice gives rise to teratomas, showing their in vivo multilineage differentiation capacity. To prevent this important complication, in a hypothetic therapeutic approach, iPSCs should be differentiated in vitro into the required cell lineage and differentiated cells should then be selected prior to their use in vivo. iPSCs are indeed the object of intense interest in human medicine already holding promise for instance for the therapy of retinal diseases (93).

RANKL deficiency will require a different approach. Pharmacologic treatment with recombinant soluble RANKL is in theory a good alternative. In the tnfsf11 knockout mice it has been observed the rescue of the bone phenotype and beneficial effects on the bone marrow, spleen and thymus with a systematic administration of RANKL for 1 month. The study faced the severe adverse accumulation of the cytokine with consequent lethal overdose, likely inducing an expansion of lymphoid aggregates already present in the lungs of untreated mice and subsequent respiratory failure (94). However, these adverse effects could be prevented by dose titration and skeletal monitoring followed by dose tapering when the skeletal phenotype is rescued.

In the context of this form of osteopetrosis, two further lines of research are currently being pursued: skeletal (mesenchymal) stem cell transplant and biotechnological implants.

Skeletal stem cells are mesenchymal in origin. They replenish the osteoblast component of bone and support hematopoiesis (76). Therefore, they are theoretically ideal to be allo- or autotransplanted to generate an osteoblast population capable of producing RANKL, even upon gene manipulation or genome editing procedures. Unfortunately, there are no applications yet of mesenchymal stem cells in medicine (77) and more studies are necessary to fully understand their 
biology prior of considering them a suitable tool to combat RANKL deficiency. Furthermore, infusion of mesenchymal stem cells for a systemic disease, that in this specific case is not hematological in origin, is still challenging and there are no studies supporting the feasibility of this procedure.

As an alternative, RANKL-producing skeletal stem or progenitor cells could be implanted subcutaneously, in specific biotechnological devices, which could then have a systemic effect by releasing soluble RANKL. This has been done in mouse models using calvarial osteoblasts inoculated in diffusion chambers along with a hydroxyapatite support functionalized by adsorption of the catalytic domain of metalloproteinase-14, an ectoenzyme that cleaves membrane bound RANKL into soluble and active RANKL (95). This biotechnological manipulation was shown to induce the release of enough soluble RANKL to trigger osteoclastogenesis in a RANKL-deficient mouse model, thus demonstrating promise for future development. The method could have several advantages, including physiologic regulation of RANKL and osteoprotegerin expression, lack of immune response against the donor cells, which are separated by the host immune system through the porous membrane of the diffusion chambers, and the possibility of inoculating the diffusion chambers with engineered cells which could express soluble RANKL in a controlled manner, theoretically preventing adverse overdose effects.

ADO2 could instead be a good candidate for RNA interfering procedures. One approach is RNA silencing, which has been successfully used in our laboratory in the heterozygous $\mathrm{Cl} c n 7^{G 213 R}$ mouse model of ADO2, based on the concept that the CLCN7 gene is haplosufficient and mutant-specific small interfering RNA (siRNA) are able to silence only the mutant gene, leaving the normal gene intact (96) (Figure 1A). We have designed siRNAs for three frequent mutations, $C L C N 7^{G 215 R}{ }_{-}$, 
$C L C N 7^{R 767 W}$ - and $C L C N 7^{R 286 W}$ which proved effective in silencing the respective mutant mRNA in transfected HEK293 cells, RAW264.7 cells and human osteoclasts. None of these siRNAs changed the expression of the normal CLCN7 mRNA and no effect was observed using control scrambled siRNA. The $C L C N 7^{G 215 R}$-specific siRNA, rescued normal bone resorption in osteoclasts harvested from a patient, as well as in osteoclasts obtained from the $C l c n 7^{G 213 R}$ mice, carrying the mouse homologue of the human mutant gene. Most importantly, this experimental therapy was effective and specific also in vivo (96). Treatment of $C l c n 7^{G 213 R}$ mice with $C L C N 7^{G 215 R}$-specific siRNA, which also complement the mouse mutant gene, improved the bone structural (Figure 1B) and cellular variables rescuing a normal bone phenotype in 4 weeks (96). We were able to obtain in vivo proof of concept of effective treatment also with siRNAs specific for the other mutants (96). Hypothetical adverse events of siRNA therapy could include non-specific off-target effects and induction of pro-inflammatory response. With our siRNA strategy targeted exclusively to the mutant gene, we did not observe any of these events nor did we note other overt adverse effects (96). These results demonstrate that a siRNA-based experimental treatment of ADO2 is feasible, and underscore a future translational impact for this strategy.

Using a similar ADO2 mouse model (same mutation, different strain) we tested whether IFN- $\gamma$ or high dose calcitriol could increase bone resorption and decrease bone mass. Six-week-old male and female ADO2 mice were treated with vehicle, calcitriol, or IFN- $\gamma$ at three different doses for 8 weeks. Mice treated with low and medium doses of calcitriol showed a trend toward higher bone mineral density and bone volume over total tissue volume, whereas high dose calcitriol significantly increased bone mass compared to vehicle (97). In contrast, all doses of IFN- $\gamma$ significantly attenuated the increase of whole body bone mineral density (97) and bone volume over total tissue volume at the distal femur in both male and female ADO2 mice as compared to 
those treated with vehicle (Figure 2A). Importantly, the reduction in bone volume due to IFN- $\gamma$ treatment was to a level approximately half way between wildtype mice and ADO2 mutant mice, indicating that there was an incomplete, but meaningful reduction in the abnormal bone phenotype. Additionally, the serum Carboxy-terminal collagen crosslinks (CTX) and the CTX/TRAcP ratio were increased in the IFN- $\gamma$ groups, but not in the calcitriol treated groups (Figure 2B), indicating that there was an increase in bone resorption with IFN- $\gamma$ treatment (97). This study demonstrates that IFN- $\gamma$ has potential to at least partially treat human ADO2 and a clinical trial in patients is currently underway (98).

\section{Conclusions}

The natural history of osteopetroses is a journey in the biology of osteoclasts and, through this group of diseases scientists gained an understanding of the molecular mechanisms underlying osteoclastogenesis and bone resorption. These pioneering studies have laid the foundation for current osteoclast biology and technological investigations and, importantly, for the comprehension of the pathogenesis of other diseases involving osteoclasts. Not only the field of osteopetrosis, but also the fields of osteoporosis and other pathological conditions in which the osteoclasts are secondarily affected (i.e. osteogenesis imperfecta, osteoporosis pseudoglioma syndrome, fibrous dysplasia, rheumatoid arthritis, juvenile idiopathic arthritis, etc.) have largely benefited from these developments, as these patients receive now anti-resorptive treatments to strengthen the bone. Unfortunately, there are still important limitations in the treatment of osteopetroses, since effective therapies are not available for all forms, can be dangerous, and do not fully rescue the phenotype. However, we look forward to forthcoming developments, which are expected to bring substantial innovation in the field, providing patients and their families with a hope for their future. 


\section{Acknowledgements}

The original work performed by AT has been supported by the Telethon Grants GGP06019, GGP09018 and GGP14014, and by the European Union funded projects SYBIL - FP7-HEALTH-2013INNOVATION - 602300 and RUBICON - H2020-MSCA-RISE-2015 - 690850. The original work performed by MJE has been supported by a grant from Horizon Pharma Ireland Ltd. 


\section{References}

1. Cappariello A, Maurizi A, Veeriah V, Teti A. The Great Beauty of the osteoclast. Arch Biochem Biophys. 2014 Sep 15;558:70-8. doi: 10.1016/j.abb.2014.06.017.

2. Teti A. Bone development: overview of bone cells and signalling. Curr Osteoporos Rep. 2011 Dec;9(4):264-73. doi: 10.1007/s11914-011-0078-8.

3. Del Fattore A, Cappariello A, Teti A. Genetics, pathogenesis and complications of osteopetrosis. Bone. 2008 Jan;42(1):19-29.

4. Whyte MP. Sclerosing Bone Disorders Primer on the Metabolic Bone Diseases and Disorders of Mineral Metabolism, Eighth Edition. Edited by Clifford J. Rosen. Keen RW, ed. John Wiley \& Sons, Inc. 2013 Chapter 93, pp. 769-785.

5. Sobacchi C, Schulz A, Coxon FP, Villa A, Helfrich MH. Osteopetrosis: genetics, treatment and new insights into osteoclast function. Nat Rev Endocrinol. 2013 Sep;9(9):522-36. doi: 10.1038/nrendo.2013.137.

6. Bolt RJ, Wennink JM, Verbeke JI, Shah GN, Sly WS, Bökenkamp A. Carbonic anhydrase type II deficiency. Am J Kidney Dis. 2005 Nov;46(5):A50, e71-3.

7. Bollerslev J, Henriksen K, Nielsen MF, Brixen K, Van Hul W. Autosomal dominant osteopetrosis revisited: lessons from recent studies. Eur J Endocrinol. 2013 Jul 13;169(2):R39-57. doi: 10.1530/EJE-13-0136.

8. Cleiren E, Bénichou O, Van Hul E, Gram J, Bollerslev J, Singer FR, Beaverson K, Aledo A, Whyte MP, Yoneyama T, deVernejoul MC, Van Hul W. Albers-Schönberg disease (autosomal dominant osteopetrosis, type II) results from mutations in the ClCN7 chloride channel gene. Hum Mol Genet. 2001 Dec 1;10(25):2861-7.

9. Frattini A, Pangrazio A, Susani L, Sobacchi C, Mirolo M, Abinun M, Andolina M, Flanagan A, Horwitz EM, Mihci E, Notarangelo LD, Ramenghi U, Teti A, Van Hove J, Vujic D, Young T, 
Albertini A, Orchard PJ, Vezzoni P, Villa A. Chloride channel CICN7 mutations are responsible for severe recessive, dominant, and intermediate osteopetrosis. $\underline{J \text { Bone Miner }}$ Res. 2003 Oct;18(10):1740-7.

10. Zhang ZL, He JW, Zhang H, Hu WW, Fu WZ, Gu JM, Yu JB, Gao G, Hu YQ, Li M, Liu YJ. Identification of the CLCN7 gene mutations in two Chinese families with autosomal dominant osteopetrosis (type II). J Bone Miner Metab. 2009;27(4):444-51. doi: 10.1007/s00774-009-0051-0.

11. Pangrazio A, Pusch M, Caldana E, Frattini A, Lanino E, Tamhankar PM, Phadke S, Lopez AG, Orchard P, Mihci E, Abinun M, Wright M, Vettenranta K, Bariae I, Melis D, Tezcan I, Baumann C, Locatelli F, Zecca M, Horwitz E, Mansour LS, Van Roij M, Vezzoni P, Villa A, Sobacchi C. Molecular and clinical heterogeneity in CLCN7-dependent osteopetrosis: report of 20 novel mutations. Hum Mutat. 2010 Jan;31(1):E1071-80. doi: 10.1002/humu.21167.

12. Wang C, Zhang H, He JW, Gu JM, Hu WW, Hu YQ, Li M, Liu YJ, Fu WZ, Yue H, Ke YH, Zhang ZL. The virulence gene and clinical phenotypes of osteopetrosis in the Chinese population: six novel mutations of the CLCN7 gene in twelve osteopetrosis families. J Bone Miner Metab. 2012 May;30(3):338-48. doi: 10.1007/s00774-011-0319-z.

13. Yao L, Seeger LL. Epiphyseal growth arrest lines. MR findings. Clin Imaging. 1997 JulAug;21(4):237-40.

14. de Vernejoul MC, Kornak U. Heritable sclerosing bone disorders: presentation and new molecular mechanisms. Ann N Y Acad Sci. 2010 Mar;1192:269-77. doi: 10.1111/j.17496632.2009.05244.x.

15. Driessen, G.J., E.J. Gerritsen, A. Fischer, A. Fasth, W.C. Hop, P. Veys, F. Porta, A. Cant, C.G. Steward, J.M. Vossen, D. Uckan and W. Friedrich. 2003. Long-term outcome of 
haematopoietic stem cell transplantation in autosomal recessive osteopetrosis: an EBMT report. Bone Marrow Transplant. 32: 657-663.

16. Kornak U, Kasper D, Bo MR, Kaiser E, Schweizer M, Schulz A, Friedrich W, Delling G, Jentsch TJ. Loss of the CIC7 chloride channel leads to osteopetrosis in mice and man. Cell 2001 104(2):205-15.

17. Chalhoub N, Benachenhou N, Rajapurohitam V, Pata M, Ferron M, Frattini A, Villa A, Vacher J. Grey-lethal mutation induces severe malignant autosomal recessive osteopetrosis in mouse and human. Nat Med. 2003 Apr;9(4):399-406.

18. Teti A, Schulz A. Haematopoietic stem cell transplantation in autosomal recessive osteopetrosis. In Stem Cells and Bone Diseases, Chapter 15. 267-288.

19. Schinke T, Schilling AF, Baranowsky A, Seitz S, Marshall RP, Linn T, Blaeker M, Huebner AK, Schulz A, Simon R, Gebauer M, Priemel M, Kornak U, Perkovic S, Barvencik F, Beil FT, Del Fattore A, Frattini A, Streichert T, Pueschel K, Villa A, Debatin KM, Rueger JM, Teti A, Zustin J, Sauter G, Amling M. Impaired gastric acidification negatively affects calcium homeostasis and bone mass. Nat Med. 2009 Jun;15(6):674-81. doi: 10.1038/nm.1963.

20. Barvencik F, Kurth I, Koehne T, Stauber T, Zustin J, Tsiakas K, Ludwig CF, Beil FT, Pestka JM, Hahn M, Santer R, Supanchart C, Kornak U, Del Fattore A, Jentsch TJ, Teti A, Schulz A, Schinke T, Amling M. CLCN7 and TCIRG1 mutations differentially affect bone matrix mineralization in osteopetrotic individuals. J Bone Miner Res. 2014 Apr;29(4):982-91. doi: 10.1002/jbmr.2100.

21. Ye L, Morse LR, Zhang L, Sasaki H, Mills JC, Odgren PR, Sibbel G, Stanley JR, Wong G, Zamarioli A, Battaglino RA. Osteopetrorickets due to Snx10 deficiency in mice results from both failed osteoclast activity and loss of gastric acid-dependent calcium absorption. PLoS Genet. 2015 Mar 26;11(3):e1005057. doi: 10.1371/journal.pgen.1005057. 
22. Sobacchi C, Frattini A, Guerrini MM, Abinun M, Pangrazio A, Susani L, Bredius R, Mancini G, Cant A, Bishop N, Grabowski P, Del Fattore A, Messina C, Errigo G, Coxon FP, Scott DI, Teti A, Rogers MJ, Vezzoni P, Villa A, Helfrich MH. Osteoclast-poor human osteopetrosis due to mutations in the gene encoding RANKL. Nat Genet. 2007 Aug;39(8):960-2.

23. Guerrini MM, Sobacchi C, Cassani B, Abinun M, Kilic SS, Pangrazio A, Moratto D, Mazzolari E, Clayton-Smith J, Orchard P, Coxon FP, Helfrich MH, Crockett JC, Mellis D, Vellodi A, Tezcan I, Notarangelo LD, Rogers MJ, Vezzoni P, Villa A, Frattini A. Human osteoclast-poor osteopetrosis with hypogammaglobulinemia due to TNFRSF11A (RANK) mutations. Am J Hum Genet. 2008 Jul;83(1):64-76. doi: 10.1016/j.ajhg.2008.06.015.

24. Villa A, Guerrini MM, Cassani B, Pangrazio A, Sobacchi C. Infantile malignant, autosomal recessive osteopetrosis: the rich and the poor. Calcif Tissue Int. 2009 Jan;84(1):1-12. doi: 10.1007/s00223-008-9196-4.

25. Del Fattore A, Peruzzi B, Rucci N, Recchia I, Cappariello A, Longo M, Fortunati D, Ballanti P, lacobini M, Luciani M, Devito R, Pinto R, Caniglia M, Lanino E, Messina C, Cesaro S, Letizia C, Bianchini G, Fryssira H, Grabowski P, Shaw N, Bishop N, Hughes D, Kapur RP, Datta HK, Taranta A, Fornari R, Migliaccio S, Teti A. Clinical, genetic, and cellular analysis of 49 osteopetrotic patients: implications for diagnosis and treatment. J Med Genet. 2006 Apr;43(4):315-25.

26. Hiroyama Y, Miike T, Sugino S, Taku K. Creatine kinase brain isoenzyme in infantile osteopetrosis. Pediatr Neurol. 1987 Jan-Feb;3(1):54-7.

27. Ohlsson A, Cumming WA, Paul A, Sly WS. Carbonic anhydrase II deficiency syndrome: recessive osteopetrosis with renal tubular acidosis and cerebral calcification. Pediatrics. 1986 Mar;77(3):371-81.

28. Arnett TR. Extracellular pH regulates bone cell function. J Nutr. 2008 Feb;138(2):415S-418S. 
29. Van Wesenbeeck L, Cleiren E, Gram J, Beals RK, Bénichou O, Scopelliti D, Key L, Renton T, Bartels C, Gong Y, Warman ML, De Vernejoul MC, Bollerslev J, Van Hul W. Six novel missense mutations in the LDL receptor-related protein 5 (LRP5) gene in different conditions with an increased bone density. Am J Hum Genet. 2003 Mar;72(3):763-71.

30. Pangrazio A, Boudin E, Piters E, Damante G, Lo lacono N, D'Elia AV, Vezzoni P, Van Hul W, Villa A, Sobacchi C. Identification of the first deletion in the LRP5 gene in a patient with autosomal dominant osteopetrosis type I. Bone. 2011 Sep;49(3):568-71. doi: 10.1016/j.bone.2011.05.006.

31. Waguespack SG, Hui SL, Dimeglio LA, Econs MJ. Autosomal dominant osteopetrosis: clinical severity and natural history of 94 subjects with a chloride channel 7 gene mutation. J Clin Endocrinol Metab. 2007 Mar;92(3):771-8.

32. Bénichou OD, Laredo JD, de Vernejoul MC. Type II autosomal dominant osteopetrosis (Albers-Schönberg disease): clinical and radiological manifestations in 42 patients. Bone. 2000 Jan;26(1):87-93.

33. Gram J, Antonsen S, Hørder M, Bollerslev J. Elevated serum levels of creatine kinase BB in autosomal dominant osteopetrosis type II. Calcif Tissue Int. 1991 Jun;48(6):438-9.

34. Whyte MP, Chines A, Silva DP Jr, Landt Y, Ladenson JH. Creatine kinase brain isoenzyme (BB-CK) presence in serum distinguishes osteopetroses among the sclerosing bone disorders. J Bone Miner Res. 1996 Oct;11(10):1438-43.

35. Marks SC Jr, Walker DG. The hematogenous origin of osteoclasts: experimental evidence from osteopetrotic (microphthalmic) mice treated with spleen cells from beige mouse donors. Am J Anat. 1981 May;161(1):1-10.

36. Walker DG. The classic: Osteopetrosis cured by temporary parabiosis. Clin Orthop Relat Res. 1982 Jan-Feb;(162):2-3. 
37. Van Wesenbeeck L, Van Hul W. Lessons from osteopetrotic mutations in animals: impact on our current understanding of osteoclast biology. Crit Rev Eukaryot Gene Expr. $2005 ; 15(2): 133-62$.

38. Scimeca JC, Franchi A, Trojani C, Parrinello H, Grosgeorge J, Robert C, Jaillon O, Poirier C, Gaudray P, Carle GF. The gene encoding the mouse homologue of the human osteoclastspecific 116-kDa V-ATPase subunit bears a deletion in osteosclerotic (oc/oc) mutants. Bone. 2000 Mar;26(3):207-13.

39. Van Wesenbeeck L, Odgren PR, Coxon FP, Frattini A, Moens P, Perdu B, MacKay CA, Van Hul E, Timmermans JP, Vanhoenacker F, Jacobs R, Peruzzi B, Teti A, Helfrich MH, Rogers MJ, Villa A, Van Hul W. Involvement of PLEKHM1 in osteoclastic vesicular transport and osteopetrosis in incisors absent rats and humans. J Clin Invest. 2007 Apr;117(4):919-30.

40. Soriano P, Montgomery C, Geske R, Bradley A. Targeted disruption of the c-src protooncogene leads to osteopetrosis in mice. Cell. 1991 Feb 22;64(4):693-702.

41. Kim N, Odgren PR, Kim DK, Marks Jr SC, Choi Y. Diverse roles of the tumor necrosis factor family member TRANCE in skeletal physiology revealed by TRANCE deficiency and partial rescue by a lymphocyte-expressed TRANCEtransgene. Proc Natl Acad Sci U S A 2000;97:10905e10.

42. Taranta A, Migliaccio S, Recchia I, Caniglia M, Luciani M, De Rossi G, Dionisi-Vici C, Pinto RM, Francalanci P, Boldrini R, Lanino E, Dini G, Morreale G, Ralston SH, Villa A, Vezzoni P, Del Principe D, Cassiani F, Palumbo G, Teti A. Genotype-phenotype relationship in human ATP6i-dependent autosomal recessive osteopetrosis. Am J Pathol. 20031 Jan; 62:57-68.

43. Helfrich MH. Osteoclast diseases. Microsc Res Tech. 2003 Aug 15;61(6):514-32. 
44. Jacome-Galarza CE, Lee SK, Lorenzo JA, Aguila HL. Parathyroid hormone regulates the distribution and osteoclastogenic potential of hematopoietic progenitors in the bone marrow. J Bone Miner Res. 2011 Jun;26(6):1207-16. doi: 10.1002/jbmr.324.

45. Hendy GN, Canaff L Calcium-sensing receptor, proinflammatory cytokines and calcium homeostasis. Semin Cell Dev Biol. 2016 Jan;49:37-43. doi: 10.1016/j.semcdb.2015.11.006

46. Silva BC, Costa AG, Cusano NE, Kousteni S, Bilezikian JP.Catabolic and anabolic actions of parathyroid hormone on the skeleton. J Endocrinol Invest. 2011 Nov;34(10):801-10. doi: $10.3275 / 7925$.

47. Pierroz DD, Rufo A, Bianchi EN, Glatt V, Capulli M, Rucci N, Cavat F, Rizzoli R, Teti A, Bouxsein ML, Ferrari SL. Beta-Arrestin2 regulates RANKL and ephrins gene expression in response to bone remodeling in mice. J Bone Miner Res. 2009 May;24(5):775-84. doi: 10.1359/jbmr.081237.

48. Henriksen K, Gram J, Schaller S, Dahl BH, Dziegiel MH, Bollerslev J, Karsdal MA. Characterization of osteoclasts from patients harboring a G215R mutation in ClC-7 causing autosomal dominant osteopetrosis type II. Am J Pathol. 2004 May;164(5):1537-45.

49. Karsdal MA, Henriksen K, Sørensen MG, Gram J, Schaller S, Dziegiel MH, Heegaard AM, Christophersen P, Martin TJ, Christiansen C, Bollerslev J. Acidification of the osteoclastic resorption compartment provides insight into the coupling of bone formation to bone resorption. Am J Pathol. 2005 Feb;166(2):467-76.

50. Teti A. Osteoclasts and hematopoiesis. Bonekey Rep. 2012 Mar 28;1:46. doi: 10.1038/bonekey.2012.46.

51. Frattini A, Orchard PJ, Sobacchi C, Giliani S, Abinun M, Mattsson JP, Keeling DJ, Andersson AK, Wallbrandt P, Zecca L, Notarangelo LD, Vezzoni P, Villa A. Defects in TCIRG1 subunit of 
the vacuolar proton pump are responsible for a subset of human autosomal recessive osteopetrosis. Nat Genet. 2000 Jul;25(3):343-6.

52. Rucci N, Teti A. The "love-hate" relationship between osteoclasts and bone matrix. Matrix Biol. 2016 May-Jul;52-54:176-90. doi: 10.1016/j.matbio.2016.02.009.

53. Leisle L, Ludwig CF, Wagner FA, Jentsch TJ, Stauber T. ClC-7 is a slowly voltage-gated 2Cl()/1H(+)-exchanger and requires Ostm1 for transport activity. EMBO J. 2011 Jun 1;30(11):2140-52. doi: 10.1038/emboj.2011.137.

54. An SNX10 mutation causes malignant osteopetrosis of infancy. Aker M, Rouvinski A, Hashavia S, Ta-Shma A, Shaag A, Zenvirt S, Israel S, Weintraub M, Taraboulos A, Bar-Shavit Z, Elpeleg O. J Med Genet. 2012 Apr;49(4):221-6. doi: 10.1136/jmedgenet-2011-100520.

55. Pangrazio A, Cassani B, Guerrini MM, Crockett JC, Marrella V, Zammataro L, Strina D, Schulz A, Schlack C, Kornak U, Mellis DJ, Duthie A, Helfrich MH, Durandy A, Moshous D, Vellodi A, Chiesa R, Veys P, Lo lacono N, Vezzoni P, Fischer A, Villa A, Sobacchi C. RANK-dependent autosomal recessive osteopetrosis: characterization of five new cases with novel mutations. J Bone Miner Res. 2012 Feb;27(2):342-51. doi: 10.1002/jbmr.5.

56. Döffinger R, Smahi A, Bessia C, Geissmann F, Feinberg J, Durandy A, Bodemer C, Kenwrick S, Dupuis-Girod S, Blanche S, Wood P, Rabia SH, Headon DJ, Overbeek PA, Le Deist F, Holland SM, Belani K, Kumararatne DS, Fischer A, Shapiro R, Conley ME, Reimund E, Kalhoff $H$, Abinun M, Munnich A, Israël A, Courtois G, Casanova JL. X-linked anhidrotic ectodermal dysplasia with immunodeficiency is caused by impaired NF-kappaB signaling. Nat Genet. 2001 Mar;27(3):277-85.

57. Darwech I, Otero J, Alhawagri M, Dai S, Abu-Amer Y. Impediment of NEMO oligomerization inhibits osteoclastogenesis and osteolysis. J Cell Biochem. 2009 Dec 15;108(6):1337-45. 
58. McEwan DG, Dikic I. PLEKHM1: Adapting to life at the lysosome. Autophagy. 2015 Apr 3;11(4):720-2. doi: 10.1080/15548627.2015.1034419.

59. Becker HM, Klier M, Schüler C, McKenna R, Deitmer JW. Intramolecular proton shuttle supports not only catalytic but also noncatalytic function of carbonic anhydrase II. Proc Natl Acad Sci U S A. 2011 Feb 15;108(7):3071-6. doi: 10.1073/pnas.1014293108.

60. Teti A, Blair HC, Teitelbaum SL, Kahn AJ, Koziol C, Konsek J, Zambonin-Zallone A, Schlesinger $\mathrm{PH}$. Cytoplasmic $\mathrm{pH}$ regulation and chloride/bicarbonate exchange in avian osteoclasts. J Clin Invest. 1989 Jan;83(1):227-33.

61. Lindsey AE, Schneider K, Simmons DM, Baron R, Lee BS, Kopito RR. Functional expression and subcellular localization of an anion exchanger cloned from choroid plexus. Proc Natl Acad Sci U S A. 1990 Jul;87(14):5278-82.

62. Borthwick KJ, Kandemir N, Topaloglu R, Kornak U, Bakkaloglu A, Yordam N, Ozen S, Mocan H, Shah GN, Sly WS, Karet FE. A phenocopy of CAll deficiency: a novel genetic explanation for inherited infantile osteopetrosis with distal renal tubular acidosis. J Med Genet. 2003 Feb;40(2):115-21.

63. Kornak U, Bösl MR, Kubisch C. Complete genomic structure of the CLCN6 and CLCN7 putative chloride channel genes(1). Biochim Biophys Acta. 1999 Oct 6;1447(1):100-6.

64. Chen X, Zhang K, Hock J, Wang C, Yu X. Enhanced but hypofunctional osteoclastogenesis in an autosomal dominant osteopetrosis type II case carrying a c.1856C\&gt;T mutation in CLCN7. Bone Res. 2016 Nov 29;4:16035.

65. Deng H, He D, Rong P, Xu H, Yuan L, Li L, Lu Q, Guo Y. Novel CLCN7 mutation identified in a Han Chinese family with autosomal dominant osteopetrosis-2. Mol Pain. 2016 Jun 20;12. pii: 1744806916652628 . doi: 10.1177/1744806916652628. 
66. Pang Q, Chi Y, Zhao Z, Xing X, Li M, Wang O, Jiang Y, Liao R, Sun Y, Dong J, Xia W. Novel mutations of CLCN7 cause autosomal dominant osteopetrosis type II (ADO-II) and intermediate autosomal recessive osteopetrosis (IARO) in Chinese patients. Osteoporos Int. 2016 Mar;27(3):1047-55. doi: 10.1007/s00198-015-3320-x.

67. Zheng H, Shao C, Zheng Y, He JW, Fu WZ, Wang C, Zhang ZL. Two novel mutations of CLCN7 gene in Chinese families with autosomal dominant osteopetrosis (type II). J Bone Miner Metab. 2016 Jul;34(4):440-6. doi: 10.1007/s00774-015-0682-2.

68. Zheng H, Zhang Z, He JW, Fu WZ, Wang C, Zhang ZL. Identification of two novel CLCN7 gene mutations in three Chinese families with autosomal dominant osteopetrosis type II. Joint Bone Spine. 2014 Mar;81(2):188-9. doi: 10.1016/j.jbspin.2013.06.014.

69. Chu K, Koller DL, Ichikawa S, Snyder R, Curry L, Lai D, Austin A, Xuei X, Edenberg HJ, Hui SL, Foroud TM, Peacock M, Econs MJ. CLCN7 polymorphisms and bone mineral density in healthy premenopausal white women and in white men. Bone. 2008 Dec;43(6):995-8. doi: 10.1016/j.bone.2008.07.249.

70. Kornak U, Ostertag A, Branger S, Benichou O, de Vernejoul MC. Polymorphisms in the CLCN7 gene modulate bone density in postmenopausal women and in patients with autosomal dominant osteopetrosis type II. J Clin Endocrinol Metab. 2006 Mar;91(3):9951000.

71. Pettersson U, Albagha OM, Mirolo M, Taranta A, Frattini A, McGuigan FE, Vezzoni P, Teti A, van Hul W, Reid DM, Villa A, Ralston SH. Polymorphisms of the CLCN7 gene are associated with BMD in women. J Bone Miner Res. 2005 Nov;20(11):1960-7.

72. Maurizi A, Capulli M, Cortes J, Di Rito L, Rucci N, Teti A. Storage disease and neurological phenotype in autosomal dominant osteopetrosis type 2 (ADO2). A preclinical study. Bone Abstracts (2016) 5:HT1. 
73. Alam I, Gray AK, Chu K, Ichikawa S, Mohammad KS, Capannolo M, Capulli M, Maurizi A, Muraca M, Teti A, Econs MJ, Del Fattore A. Generation of the first autosomal dominant osteopetrosis type II (ADO2) disease models. Bone. 2014 Feb;59:66-75. doi: 10.1016/j.bone.2013.10.021.

74. Walker DG Bone resorption restored in osteopetrotic mice by transplants of normal bone marrow and spleen cells. Science. 1975 Nov 21;190(4216):784-5.

75. Takahashi N, Udagawa N, Suda T. A new member of tumor necrosis factor ligand family, ODF/OPGL/TRANCE/RANKL, regulates osteoclast differentiation and function. Biochem Biophys Res Commun. 1999 Mar 24;256(3):449-55.

76. Bianco P, Robey PG. Skeletal stem cells. Development. 2015 Mar 15;142(6):1023-7.

77. Zhao K, Liu Q. The clinical application of mesenchymal stromal cells in hematopoietic stem cell transplantation. J Hematol Oncol. 2016 May 18;9(1):46. doi: 10.1186/s13045-0160276-z.

78. Prockop DJ. The exciting prospects of new therapies with mesenchymal stromal cells. Cytotherapy. 2017 Jan;19(1):1-8. doi: 10.1016/j.jcyt.2016.09.008.

79. Nitkin CR, Bonfield TL. Concise Review: Mesenchymal Stem Cell Therapy for Pediatric Disease: Perspectives on Success and Potential Improvements. Stem Cells Transl Med. 2016 Sep 13. pii: sctm.2015-0427. [Epub ahead of print]

80. Chan JK, Götherström C. Prenatal transplantation of mesenchymal stem cells to treat osteogenesis imperfecta. Front Pharmacol. 2014 Oct 9;5:223. doi: 10.3389/fphar.2014.00223.

81. Girdlestone J. Mesenchymal stromal cells with enhanced therapeutic properties. Immunotherapy. 2016 Dec;8(12):1405-1416. doi: 10.2217/imt-2016-0098. 
82. Munneke JM, Spruit MJ, Cornelissen AS, van Hoeven V, Voermans C, Hazenberg MD. The Potential of Mesenchymal Stromal Cells as Treatment for Severe Steroid-Refractory Acute Graft-Versus-Host Disease: A Critical Review of the Literature. Transplantation. 2016 Nov;100(11):2309-2314.

83. Schulz SA, Moshous D, Steward CG, Villa A, Sobacchi C. Osteopetrosis. Consensus guidelines for diagnosis, therapy and follow-up. Version 3. https://www.ebmt.org/Contents/Research/TheWorkingParties/IEWP/Documents/O0_OP_ Guidelines_V3.pdf.

84. Key LL Jr, Rodriguiz RM, Willi SM, Wright NM, Hatcher HC, Eyre DR, Cure JK, Griffin PP, Ries WL. Long-term treatment of osteopetrosis with recombinant human interferon gamma. $\mathrm{N}$ Engl J Med. 1995 Jun 15;332(24):1594-9.

85. Saigal A, Gopal M, Mohanty N, Misra SR. Recurrent osteomyelitis of the mandible in osteopetrosis: a common complication of an uncommon disease. BMJ Case Rep. 2015 Jun 8;2015. doi: 10.1136/bcr-2014-208974.

86. Glorieux FH, Pettifor JM, Marie PJ, Delvin EE, Travers R, Shepard N. Induction of bone resorption by parathyroid hormone in congenital malignant osteopetrosis. Metab Bone Dis Relat Res. 1981;3(2):143-50.

87. Blazar BR, Fallon MD, Teitelbaum SL, Ramsay NK, Brown DM Calcitriol for congenital osteopetrosis. N Engl J Med. 1984 Jul 5;311(1):55.

88. Key LL Jr, Ries WL Osteopetrosis. The pharmaco-physiologic basis of therapy. Clin Orthop Relat Res. 1993 Sep;(294):85-9.

89. Askmyr M, Flores C, Fasth A, Richter J. Prospects for gene therapy of osteopetrosis. Curr Gene Ther. 2009 Jun;9(3):150-9. 
90. Sessa M, Lorioli L, Fumagalli F, Acquati S, Redaelli D, Baldoli C, Canale S, Lopez ID, Morena F, Calabria A, Fiori R, Silvani P, Rancoita PM, Gabaldo M, Benedicenti F, Antonioli G, Assanelli A, Cicalese MP, Del Carro U, Sora MG, Martino S, Quattrini A, Montini E, Di Serio C, Ciceri F, Roncarolo MG, Aiuti A, Naldini L, Biffi A. Lentiviral haemopoietic stem-cell gene therapy in early-onset metachromatic leukodystrophy: an ad-hoc analysis of a nonrandomised, open-label, phase 1/2 trial. Lancet. 2016 Jun 8. pii: S0140-6736(16)30374-9. doi: 10.1016/S0140-6736(16)30374-9.

91. Niu X, He W, Song B, Ou Z, Fan D, Chen Y, Fan $Y$, Sun X. Combining single-strand oligodeoxynucleotides and CRISPR/Cas9 to correct gene mutations in Beta-thalassemiainduced Pluripotent Stem Cells. J Biol Chem. 2016 Jun 10. pii: jbc.M116.719237. doi: 10.1074/jbc.M116.719237.

92. Neri T, Muggeo S, Paulis M, Caldana ME, Crisafulli L, Strina D, Focarelli ML, Faggioli F, Recordati C, Scaramuzza S, Scanziani E, Mantero S, Buracchi C, Sobacchi C, Lombardo A, Naldini L, Vezzoni P, Villa A, Ficara F. Targeted Gene Correction in Osteopetrotic-Induced Pluripotent Stem Cells for the Generation of Functional Osteoclasts. Stem Cell Reports. 2015 Oct 13;5(4):558-68. doi: 10.1016/j.stemcr.2015.08.005.

93. Fields M, Cai H, Gong J, Del Priore L. Potential of Induced Pluripotent Stem Cells (iPSCs) for Treating Age-Related Macular Degeneration (AMD). Cells. 2016 Dec 8;5(4). pii: E44.

94. Lo lacono N, Blair HC, Poliani PL, Marrella V, Ficara F, Cassani B, Facchetti F, Fontana E, Guerrini MM, Traggiai E, Schena F, Paulis M, Mantero S, Inforzato A, Valaperta S, Pangrazio A, Crisafulli L, Maina V, Kostenuik P, Vezzoni P, Villa A, Sobacchi C. Osteopetrosis rescue upon RANKL administration to RankI(-/-) mice: a new therapy for human RANKL-dependent ARO. J Bone Miner Res. 2012 Dec;27(12):2501-10. doi: 10.1002/jbmr.1712. 
95. Cappariello A, Paone R, Maurizi A, Capulli M, Rucci N, Muraca M, Teti A. Biotechnological approach for systemic delivery of membrane Receptor Activator of NF-kB Ligand RANKL) active domain into the circulation. Biomaterials. 2015 Apr;46:58-69. doi: 10.1016/j.biomaterials.2014.12.033.

96. Capulli M, Maurizi A, Ventura L, Rucci N, Teti A. Effective small interfering RNA therapy to treat CLCN7-dependent autosomal dominant osteopetrosis type 2. Mol Ther Nucleic Acids. 2015 Sep 1;4:e248. doi: 10.1038/mtna.2015.21.

97. Alam I, Gray AK, Acton D, Gerard-O'Riley RL, Reilly AM, Econs MJ. Interferon gamma, but not calcitriol improves the osteopetrotic phenotypes in ADO2 mice. J Bone Miner Res. 2015 Nov;30(11):2005-13. doi: 10.1002/jbmr.2545.

98. Use of ACTIMMUNE in patients with ADO2. https://clinicaltrials.gov/ct2/show/NCT02584608. 
Table 1: Forms of osteopetroses, genes implicated and phenotype.

\begin{tabular}{|c|c|c|c|}
\hline Form & Gene & $\begin{array}{l}\text { Osteoclast } \\
\text { phenotype }\end{array}$ & $\begin{array}{l}\text { Clinical } \\
\text { Phenotype }\end{array}$ \\
\hline Autosomal & TCIRG1 & Rich & Severe, osteopetrorickets \\
\hline \multirow[t]{5}{*}{ Recessive } & CLCN-7 & Rich & Severe, possible neurodegeneration \\
\hline & OSTM1 & Rich & Severe, neurodegeneration \\
\hline & TNFRSF11A & Poor & Severe \\
\hline & TNFSF11 & Poor & Severe, osteoblast-intrinsic defect \\
\hline & SNX10 & Rich (?) & Severe, osteopetrorickets \\
\hline Intermediate & PLEKHMI & Rich & Intermediate \\
\hline Recessive & $C A \|$ & Rich & $\begin{array}{l}\text { Intermediate, renal tubular acidosis, cerebral } \\
\text { calcifications }\end{array}$ \\
\hline $\begin{array}{l}\text { Autosomal } \\
\text { Dominant }\end{array}$ & CLCN-7 & Rich & From mild to severe, rarely lethal \\
\hline X-linked & NEMO & Poor (?) & Severe, immunodeficiency, ectodermal dysplasia \\
\hline
\end{tabular}




\section{Figure legends}

Figure 1 - Treatment of ADO2 mice with mutant-specific siRNA. (A) Rational for the use of siRNA therapy in ADO2. ClC-7 protein is a homodimer. In healthy individuals, both subunits are normal (NN), while in $A D O 2$ one or both subunits are mutated $(\mathrm{M})$, giving rise to nonfunctional or malfunctional heterodimers (NM) or homodimers (MM). The CLCN7 gene is haplosufficient, therefore removal of the mutant subunits through highly specific siRNA that does not affect the expression of the normal subunits is expected to return the phenotype near to a physiologic condition. (B) Ten-day old $C l c n 7^{G 213 R / W T}$ ADO2 mice were treated for 2 weeks with $4 \mathrm{mg} / \mathrm{Kg}$ $C l c n 7^{G 213 R}$-specific siRNA or scrambled siRNA as control. Micro-computed tomography of the proximal tibias reveals a lower trabecular volume over total bone volume (BV/TV) in $C l c n 7^{G 213 R_{-}}$ specific siRNA-treated mice. $\mathrm{N}=6-8$. Mean+standard deviation; $\mathrm{p}=0.04$, Student's $t$ test.

\section{Figure 2 - Interferon- $\gamma$ significantly attenuated the BV/TV gain and increased the serum} CTX/TRAP ratio in ADO2 mice. ADO2 mice treated with all doses of INF- $\gamma$ displayed (A) reduced bone volume/total volume (BV/TV) and (B) increased Carboxy-terminal collagen crosslinks over Tartrate Resistant Acid Phosphatase (CTXTRAcP) ratio, indicating increased resorption per osteoclast. $\mathrm{L}=$ low dose; $\mathrm{M}=$ medium dose; $\mathrm{H}=$ high dose $(80) . \mathrm{V}=$ vehicle. 


\title{
A Non(mal)functional
}

Functional

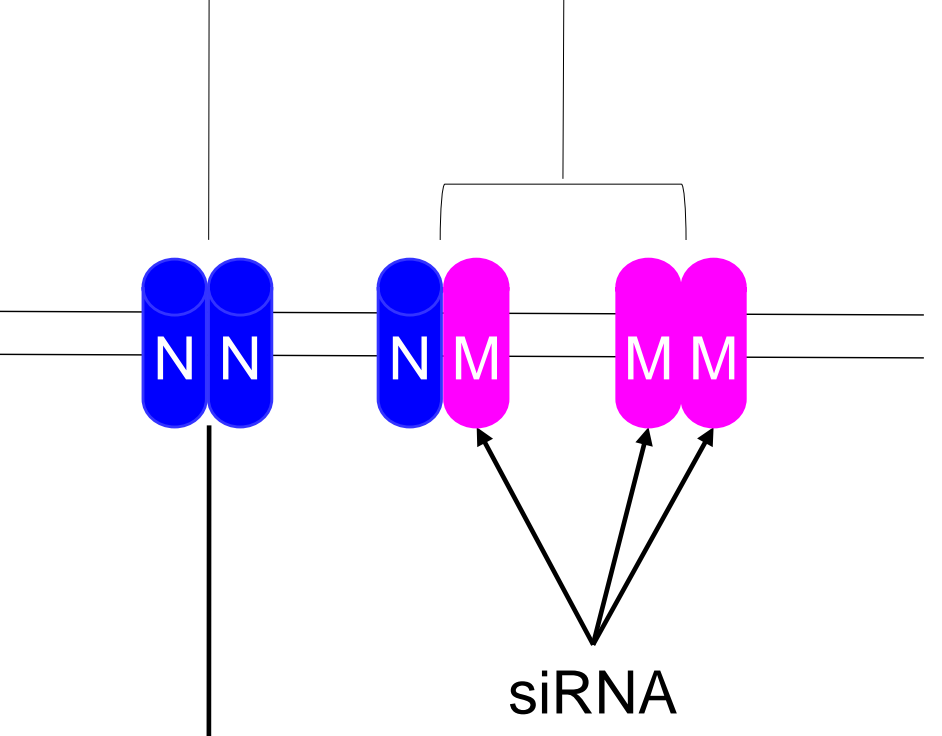

Recognizes single nucleotide change

Nearly normal phenotype

\author{
Scrambled Clcn7G213R \\ siRNA, 2-week treatment \\ BV/TV $21.53 \pm 2.31 \quad 17.42 \pm 3.89$
}

Figure 1 

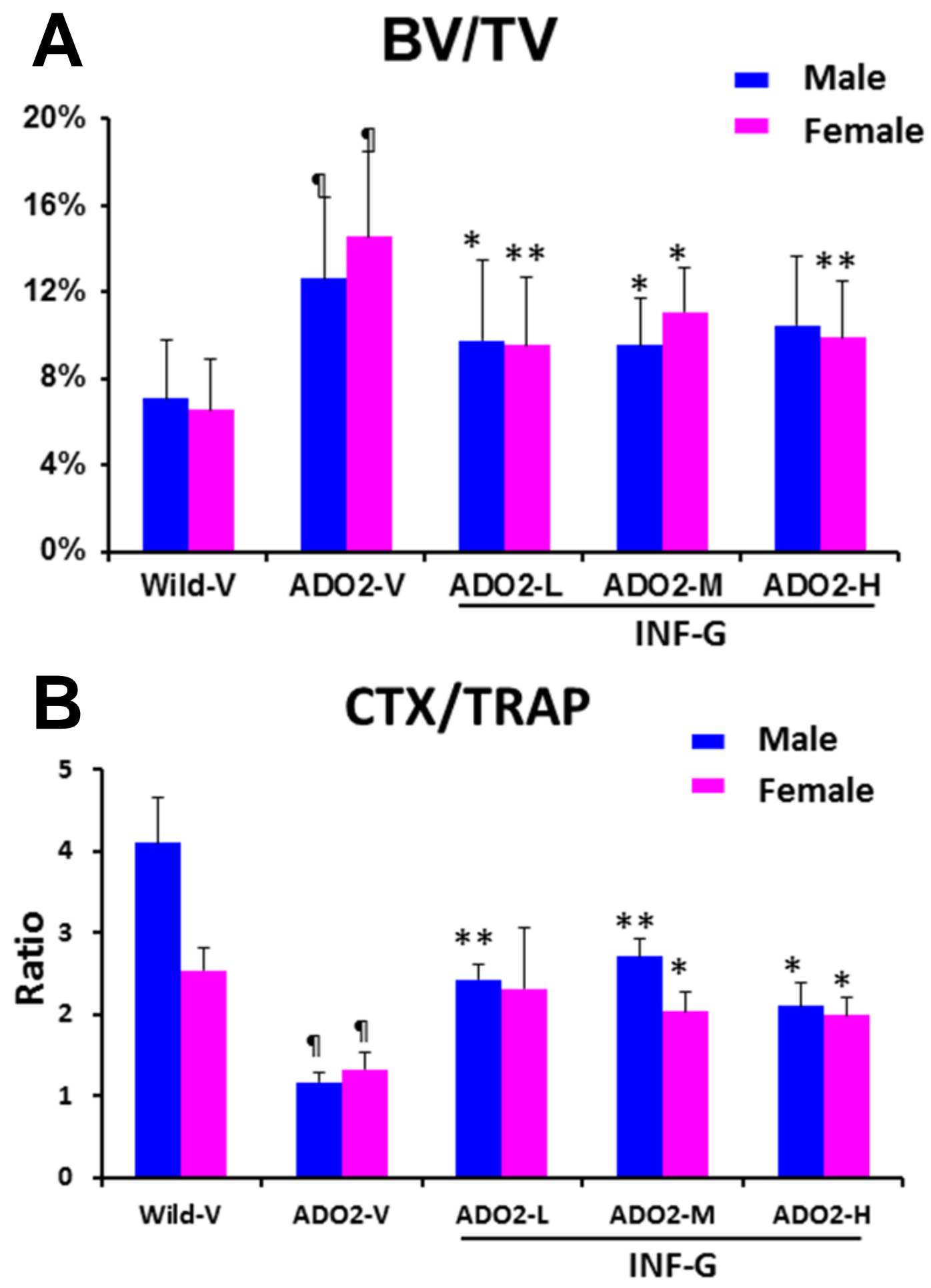

Figure 2 


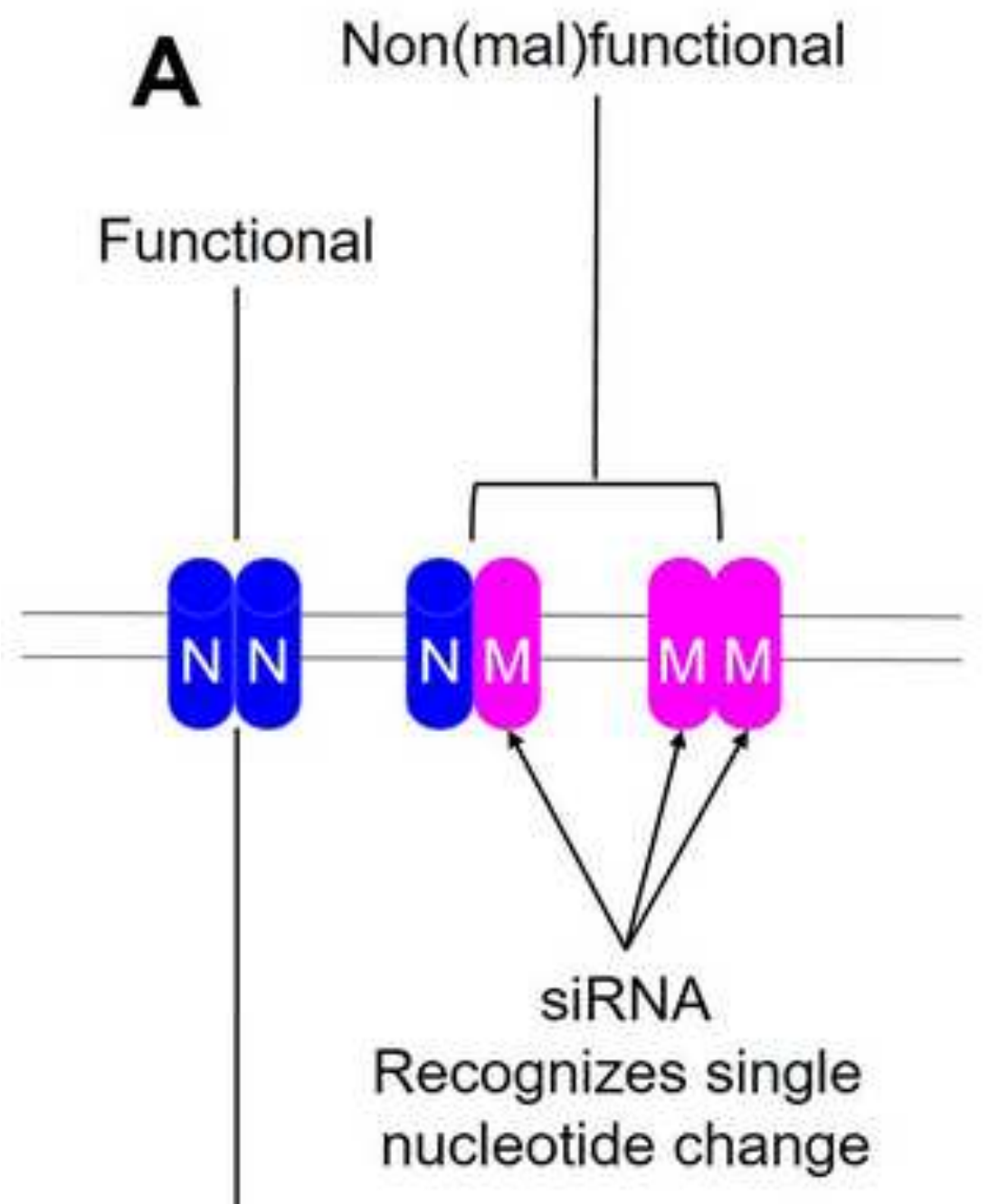

Haplosufficient

B $C l c n 7^{G 213 R W T} \mathrm{ADO} 2$ mice

Nearly normal phenotype

$$
\begin{array}{rc} 
& \multicolumn{2}{c}{\text { Scrambled }} & \multicolumn{1}{c}{\text { Clcn } 7^{\mathrm{G} 213 R}} \\
\text { BiRNA, 2-week treatment }
\end{array}
$$






